\title{
The Influence of Leadership Style, Motivation and Work Structure to Muara Enim Community Health Center Performance (Equation Structural Method Approach)
}

\author{
AlHushori ${ }^{1}$ Yusnizal Firdaus ${ }^{1}$ Markoni Badri ${ }^{1}$ Muhammad Yusuf ${ }^{1, *}$ \\ ${ }^{1}$ Business Administration Department, Polytechnic State of Sriwijaya, Palembang 30139, Indonesia \\ *Corresponding author. Email: m.yusuf@polsri.ac.id
}

\begin{abstract}
This study focus to determine the effect of leadership style and motivation on employee performance and to assist in providing suggestion related to the structure of work in the context of providing public health services. This research focus to the management of the program for the Mass Prevention of Filariasis Drugs at the Community Health Center in Muara Enim, especialy in 21 health centers. The sample in this study was the head of each community health center and filariasis officers so that the total of sample are 42 respondents. This research is a quantitative study using the Simultant Equotion Model (SEM) analysis. The SEM analysis approach was carried out by using Partial Least Square-Path Modeling. The result showed in partial way for each variable are leadership style, motivation and work structure had a significant effect on employee performance. Simultaneously, leadership style, motivation and work structure have an influence on employee performance by $70.9 \%$ and the remaining $29.1 \%$ are influenced by other factors that are not included in the study. The most influenced dimention for each variable like leadership style, motivation and work structure is the quality of work which is equal to 0.877 . In the future, performance improvement should prioritize work quality which has the indicators used in this study.
\end{abstract}

Keywords: leadership, motivation, work structure, performance.

\section{INTRODUCTION}

Based on the Regulation of the Minister of Health of the Republic of Indonesia Number 75 of 2014 concerning Community Health Centers, it is stated that the Community Health Center (Puskesmas) is a technical implementation unit of the health service led by the Head of the Puskesmas who is under and responsible to the Head of the District Health Office.

Public health efforts are any activities to maintain and improve health as well as prevent and overcome the emergence of health problems targeting families, groups and communities (Regulation of the Minister of Health of the Republic of Indonesia No. 75 of 2014).

One of the priority public health efforts is to eliminate filariasis through the provision of mass prevention drugs (POPM) to people living in endemic areas. Elephantiasis (Lymphatic Filariasis), hereinafter referred to as filariasis, is a chronic infectious disease caused by filarial worms that attack the channels and lymph nodes (Ministry of Health of the Republic of Indonesia, 2015). Community health center as the technical implementation unit of the Health Office is responsible in organizing POPM filariasis activities and is obliged to meet the community's need for quality health services in order to achieve the goal of achieving the highest possible health status for the community.

In the process of achieving goals, the performance of the health center staff is an important factor. Performance is the result of work and work behavior that has been achieved in completing the tasks and responsibilities given in a certain period. Performance can be measured from the ability of employees to complete assigned tasks and responsibilities. This means that performance contains elements of achievement standards that must be met so that if it can reach the predetermined standard, it means performed well or vice versa for those not achieved are categorized as not performing well. To improve the performance of health center employees, a leadership role is needed. Yusni Ainurahmah (2015) in his research 
on the Effect of Public Health Center Management on Access to Health Services to achieve Quality Health Services. This research was conducted at the Tarogeong Kidu sub-district health center with the results showing that the management of the community health center had a positive and significant effect on access to health services to achieve the quality of health services at the Tarogeong Kidul sub-district health center. As for the findings of the problems in this study, in terms of Community Health Center Management, it is known that the community health center officers have not been effective in attending dynamics meetings once a week, the cooperation between employees has not been effective, and the evaluation of each activity has not been effective.

Based on the report on the implementation of the activity of giving mass prevention drugs for filariasis (2016), compared to the achievement standards that must be met, it can be seen that in 2013 the provision of preventive drugs was carried out with a target of 592,080 and the total population of Muara Enim district, which was given the drug was 445,080 (75\%). In 2015 the target was 567,478 with a coverage of $480,169(85 \%)$ and in 2016 the target population was 618,000 and the population was given medicine for 495,169 (81\%). Cumulatively, the results of the coverage of mass preventive drug delivery for filariasis have fluctuated, but if you look at the coverage of taking medication in each health center / sub-district, there are 9 out of 21 puskesmas in Muara Enim Regency that has decreased significantly. This means that in puskesmas services in Muara Enim Regency, there is a need for management improvements through leadership styles, motivating employee performance to achieve health service goals and clarity in work structures for accountability to work.

\section{LITERATURE REVIEW AND HYPOTHESIS DEVELOPMENT}

\subsection{Leadership}

According to Yukl (2012) states that: Leadership is the ability of individuals to influence, motivate, and make others able to contribute to the effectiveness and success of the organization. leadership in an organization is a person's ability to influence, mobilize, encourage, control other people or their subordinates to do a job on their awareness and contribute to achieving a goal (Sutikno, 2014). So leadership is a way of influencing and motivating others so that these people want to contribute to organizational success so that leadership styles affect organizational performance and employee performance.

According to Thoha (2015) that Leadership Style is a behavior norm used by a person when that person tries to influence the behavior of others. Meanwhile, Armala (2016) states that Leadership Style is a set of characteristics used by leaders to influence subordinates so that organizational goals are achieved. This means that leadership style is behavior and strategy, as a result of a combination of philosophies, skills, traits, attitudes, which are often applied by a leader when he tries to influence the performance of his subordinates.

The leadership style according to Thoha (2015) is divided into two categories, namely autocratic leadership styles and democratic leadership styles. Autocratic leadership style is a style based on the power of position and the use of authority, while democratic leadership style is a style associated with personal strength and the participation of followers in the process of problem solving and decision making.

According to Sutikno (2014) leadership style is a leadership behavior or often called a type of leadership which consists of: autocratic type, free control type or Laisez Faire, paternalistic type, militaristic type, Pseudo-democratic type and democratic type. In relation to leader behavior, there are two things that leaders usually do to their subordinates or followers, namely directing behavior and supportive behavior. Directing behavior can be defined as the extent to which a leader involves himself in one-way communication. Forms of direction in one-way communication include determining the roles that subordinates should play, informing subordinates about what should be done, where to do work, how to do it, and supervising their subordinates closely. Supportive behavior is the extent to which a leader engages himself in two-way communication, for example listening, providing support and encouragement, fostering interaction, and involving followers in decision making.

Based on the theory of previous leadership styles, this study examines and analyzes leadership styles that are considered appropriate to the conditions at Muara Enim District Health Center by using leadership indicators according to Thoha (2015): Instructions that assess the behavior of leaders who are high in direction and low in support with indicators of one-way communication, limits on the role of subordinates, the leader informs subordinates about what, how and where tasks, problem-solving initiatives are carried out by the leader, problem solving is announced and 1) the implementation of decisions is supervised regularly. strictly by the leader 2) Consultation that assesses high behavior with high direction support with indicators: two-way communication, trying to hear the feelings of subordinates, hearing ideas and suggestions from subordinates, and decision making remains with the leader 3) Participation that assesses high behavior, low support, direction with indicators: The leader actively listens, the responsibility for problem solving is largely on the subordinates and the responsibility for decisionmaking is largely on the subordinates 4) Delegates who rate low support behavior with low direction with 
indicators of subordinates have control to decide how to carry out tasks and leaders provide ample opportunities for subordinates to carry out something.

\subsection{Motivation}

Motivation is basically a mental condition that encourages an action (action or activity) and provides strength that leads to the achievement of needs, gives satisfaction or reduces imbalance. According to Robbin \& Timothy (2017) defines motivation as a process that explains the strength, direction and persistence of a person in an effort to achieve goals. Intensity shows how hard someone tries. But high intensity is unlikely to lead to good performance results unless the effort is made in a direction that benefits the organization. Therefore, the quality of the business and its intensity must be considered. Motivation has the dimension of continuous effort. Motivation is a measure of how long a person can keep their business. The motivated individual will carry out tasks long enough to achieve their goals.

According to Thoha (2015) argues that motivation is a series of processes that arouse, direct, and maintain human behavior towards achieving goals. Motivating is the leader's duty, so that subordinates can do their job well and the goals can be achieved, thus the motivation given by the leader has the aim of:

1) Trying to make the goals that have been set in accordance with what is in a person.

2) Make efforts so that the action or action expected to be done is the same as one's ability.

3) If the goals of the organization are not the same as what is in a person's motives, the leader will find it difficult to motivate.

4) If actions, actions that must be taken are not supported by comparable abilities, the leadership will find it difficult to motivate them.

According to Robbins \& Timothy (2017) discussing that motivation can be obtained through the need to indicate a physiological or psychological deficiency that causes behavior. There are three categories of needs, which are defined as follows:

\section{a. Achievement (Achievement)}

The need for achievement is the urge to excel, to perform in relation to a set of standards, to struggle for success, including: results achieved, effort at work and attitudes towards work.

\section{b. Power (Power)}

The need for power is the need to make other people behave in a way that people (without being forced) would not behave in this way, including: social attitudes towards friends, togetherness in duties and loyalty to work.

\section{c. Affiliation / relationship (Affilation)}

The need for affiliation is the desire for friendly and intimate interpersonal relationships, including: attitudes towards leaders, prevailing norms and desire for cooperation.

\subsection{Work Structure}

Determining the position and role of human resources in an organization is an important step and at the same time becomes the basis for facing competition and strategies in advancing the organization. Policy on this matter in human resource management is related to the tendency towards determining the structure of tasks and jobs (Dessler, 2016). Although many companies (organizations) in the management of human resources and work activities are often not based on the consideration of the job structure of the members of the organization. Data about the existence of human resources is needed in an organization.

The structure, tasks and work need to be done so that what will be done is right on target and becomes the basis and flow that will facilitate the achievement of individual and organizational goals. Information and facts about a job, related to activities and responsibilities to build and improve high work motivation.

According to Dessler (2016), job structure is frequently the key to the answers to these questions. But when such problems arise, managers often blame employees rather than the structure of the job. Facts and phenomena like this are often found, because often processes in job analysis and information systems are ignored, and are not used as a policy foundation in the work structure (task). This condition can occur in all organizations, including in the health sector, health workers (responsible for POPM filariasis activities) will be blamed by the head of the puskesmas if the realization of the results of the activity is not on target. Therefore, whether or not the policy and technical measures used are appropriate, to obtain information on determining the structure of the job is very important. The collection, assessment and compilation of this information, actually for an organization, whatever the form and nature of the structured organization or not, basically already exists and is done. This is to provide a basis for assigning tasks or jobs and determining a description of the activities that are the responsibility of each job for the organization. According to Robbins \& Timothy (2017), in these cases, a manager may decide to change the way that work is done in order for the work unit to perform more effectively and efficiently. This requires redesigning the existing jobs.

The expected work behavior is in accordance with the job specifications where the work structure is a necessary factor with the support of work spirit which is the basis of work motivation and competence to be able to build everyone's commitment to task responsibilities 
in an organization in every situation. According to Dessler (2016), the job structure doesn't include work motivation for everyone in every situation, employees must have the required skills and knowledge to master the more challenging work. Therefore, the structure of work is not a simple matter, because it involves various policies that require careful attention to the needs and abilities of each individual in competence in organizational activities.

Job structure is the determination and adjustment of interdependent job tasks with certain characteristics to be carried out and completed. In this connection, the level of variable measurement is based on: Dimensions of workload with indicators: task variation and task autonomy; job function dimensions with indicators: responsibility / task authority, task information, work coordination; dimensions of job relations with indicators: work team support, and task feedback: dimensions of job adjustment with indicators: task evaluation, and task improvement \& adjustment (Yulk, 2012). Measurement of performance indicators is used in this study.

\subsection{Performance}

Performance is used to describe the results achieved by a person or group of people in doing a job or activity. According to Sutikno (2014), performance is the implementation of a job and the improvement of the work according to responsibilities so that it can achieve the results as expected. This means that performance is emphasized more on the process in which improvements are made during the execution of the work so that the achievement of work results or performance can be optimized.

According to Chandra Kirana (2017) performance is an employee's work over a certain period of time. Performance evaluation is based on a standard, objective, or other certain criteria that have been mutually agreed between employees and management.

The definition of performance according to Yulk (2016) is the quality and quantity of work achieved by an employee in carrying out his duties according to the responsibilities assigned to him. The criteria that are frequently assessed during the performance appraisal process are quantity and quality. Employee performance is the overall success rate of a person during a certain period in carrying out tasks compared to various possibilities where performance emphasizes work quantity, quality of work, timeliness, and effectiveness (Robbins, 2017).

According to As'ad (2014), the factors used in performance appraisal are as follows:

\section{Quality of work}

Quality of work is the accuracy of speed, neatness and accuracy in carrying out the assigned tasks and the skills of employees in understanding the task.

\section{Work quantity}

Work quantity is the ability to quantitatively carry out work, for example the ability to achieve predetermined job targets.

\section{Punctuality}

Timeliness is the level of an activity that is completed at the desired initial time, seen from the output of the work and can maximize the time available to be able to do other tasks

\section{Effectiveness}

Effectiveness is the level of use of organizational resources (manpower, money, technology, raw materials) maximized with the intention of increasing profits or reducing losses from each agency unit in the use of these resources.

\section{RESEARCH METHODOLOGY}

This research aim the handling of filarization patients at the community health centers in Muara Enim, especially 21 health centers. Respondents in this study consisted of one head of the health center and one manager of the filarization program in each puskesmas so that the number of respondents was 42 people. Data in this study are primary data obtained from distributing questionnaires to respondents. The analysis of this research is a quantitative analysis using the Partial Least Square-Path Modeling (PLS-PM) method. In this study the exogenous variables were leadership style, motivation and work structure, while the endogenous variables were performance.

\section{RESULT AND DISCUSSION}

\subsection{Result}

\subsubsection{The Effect of Leadership Style on Performance}

Leadership Style is hypothesized to affect employee performance:

Ho. $\gamma 1=0$ : Leadership style has no effect on employee performance

Ha. $\gamma 1 \neq 0$ : Leadership style affects employee performance.

The results of testing the first hypothesis show that the relationship between the leadership style variable and employee performance is indicated by the path coefficient value of 0.293 with a tcount of 2.404 with a $\mathrm{p}$ value of 0.021 .The $\mathrm{t}$-statistical value obtained is greater than tcritical $(1,960)$ and the $\mathrm{p}$ value is smaller than alpha value 0.05 . These results mean that the leadership style has an effect on employee performance which means it is in accordance with the first hypothesis (Hypothesis 1 is accepted). 


\subsubsection{The Effect of Motivation on Performance}

Motivation is hypothesized to affect employee performance. The following shows the results of the significance test of this hypothesis through the statistical hypothesis as follows:

Ho. $\gamma 2=0$ : Motivation has no effect on employee performance

Ha. $2 \neq 0$ : Motivation has an effect on employee performance

The results of testing the first hypothesis indicate that the relationship is variable. Motivation with employee performance is indicated by the path coefficient value of 0.272 with a tcount of 2.072 with $p$ value $=0.044$. The t-statistic value obtained is greater than tcritical $(1,960)$ and the $\mathrm{p}$ value is smaller than 0.05 . This result means that motivation has an effect on employee performance which means it is in accordance with the second hypothesis (Hypothesis 2 is accepted).

\subsubsection{Effect of Work Structure on Performance}

Job structure is hypothesized to affect employee performance. The following shows the results of the significance test of this hypothesis through the statistical hypothesis as follows:

Ho. $\gamma 3=0$ : Job structure has no effect on employee performance

Ha. $\gamma 3 \neq 0$ : Job structure has an effect on employee performance

The results of testing the first hypothesis indicate that the relationship is variable. Job Structure with Employee Performance is indicated by the path coefficient value of 0.465 with a tcount of 4.273 with $p$ value $=0.000$. The t-statistic value obtained is greater than tcritical $(1,960)$ and the $p$ value is smaller than 0.05 This result means that the work structure affects employee performance which means it is in accordance with the second hypothesis (Hypothesis 2 is accepted).

\subsubsection{The Influence of Leadership Style, Motivation and Work Structure on Employee Performance}

To determine the effect of Leadership Style, Motivation and Work Structure simultaneously on Employee Performance, then a hypothesis test is carried out by looking at the Fcount value ( $\mathrm{F}$ test). The statistical hypothesis used in testing the effect is as follows:

H0: $\mathrm{i}=0$ Leadership Style, Motivation and Work Structure simultaneously have no effect on employee performance

H0: $i \neq 0$ Leadership Style, Motivation and Work Structure simultaneously affect employee performance The value of the F-count is 30,489 . The results of the calculation of the F test statistical value obtained show that the F-count is greater than the F-table value $(\mathrm{F}=$
$30.861>2.852$ ), then the results of the $\mathrm{H} 0$ test are rejected and $\mathrm{Ha}$ is accepted. The results can be concluded that leadership style, motivation and work structure simultaneously affect employee performance.

Table 1 Simultaneous Path Coefficient Testing X-Y

\begin{tabular}{|c|c|c|c|c|}
\hline $\mathbf{R}^{2}$ & $\begin{array}{c}\mathbf{F} \\
\text { hitung }\end{array}$ & $\begin{array}{c}\mathbf{F} \\
\text { tabel }\end{array}$ & Keputusan & Kesimpulan \\
\hline 0,709 & 30,861 & 2,852 & $\mathrm{H}_{0}$ ditolak & Signifikan \\
\hline
\end{tabular}

The influence of Leadership Style, Motivation and Work Structure on Employee Performance is obtained as follows:

Results of Structural Equation Modeling (SEM) with Partial Least Square (PLS) approach to answer research problems related to the influence of Leadership Style, Motivation and Work Structure on Employee Performance. Structural equation modeling for the influence of Leadership Style, Motivation and Work Structure on Employee Performance is as follows :

$\eta=0,293 \xi_{1}+0,272 \xi_{2}+0,465 \xi_{3}+0,291$

The results of the hypothesized full model calculations are obtained with the help of Smart PLS as follows:

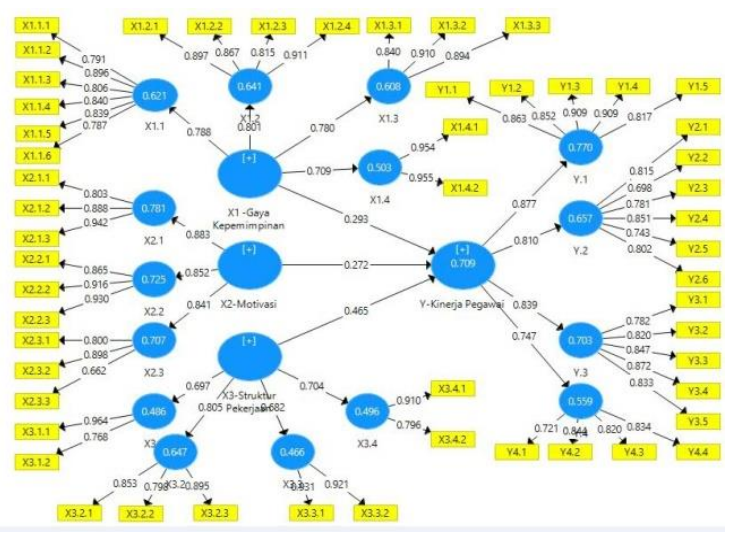

Figure 1. Model SEM approach path diagram Partial Least Square

\subsection{Discussion}

\subsubsection{Leadership Style Variable Measurement Model}

There are 4 dimensions as measurable variables (manifest variable) that form the leadership style variable. For each variable, the quality Factor of each dimension is obtained in forming the Leadership Style variable as follows: 
Table 2. Measurement Model Leadership Style variable (X1)

\begin{tabular}{|c|c|c|c|c|c|c|}
\hline & Load & & & Measur & & \\
\hline Dimension & $\begin{array}{l}\text { Facto } \\
\mathrm{r}(\lambda)\end{array}$ & $\lambda^{2}$ & $\mathrm{e}$ & $\begin{array}{c}\mathrm{e} \\
\text { Model }\end{array}$ & $\mathrm{t}_{\text {hitung }}$ & value \\
\hline $\begin{array}{l}\text { iinstructi } \\
\text { on }\end{array}$ & 0.788 & & 0.37 & $\begin{array}{c}\mathrm{X} 11= \\
0,788 \mathrm{X} \\
1+\end{array}$ & & 0.000 \\
\hline \multirow{3}{*}{ consult } & \multirow{3}{*}{0.801} & 0.621 & 9 & $\begin{array}{c}0,379 \\
X 12= \\
0,801 X\end{array}$ & 9.886 & \multirow{2}{*}{0.000} \\
\hline & & & 0.35 & $1+$ & 12.15 & \\
\hline & & 0.641 & 9 & $\begin{array}{l}0,359 \\
X 13=\end{array}$ & 9 & \\
\hline $\begin{array}{c}\text { participat } \\
\text { e }\end{array}$ & 0.780 & & 0.39 & $\begin{array}{l}0,780 \\
\mathrm{X} 1+\end{array}$ & 10.92 & 0.000 \\
\hline \multirow[t]{2}{*}{$\begin{array}{c}\text { delegatio } \\
\mathrm{n}\end{array}$} & \multirow[t]{2}{*}{0.709} & 0.608 & 0.49 & $\begin{array}{c}0,392 \\
X 14= \\
0,709 \\
X 1+\end{array}$ & 7 & \multirow[t]{2}{*}{0.000} \\
\hline & & 0.503 & 7 & 0,497 & 4.238 & \\
\hline
\end{tabular}

The results from calculating of loading factor for 4 dimensions of the latent variable Leadership Style (X1) ranged from $0.7-0.9$. The calculation result of the outer model value or the correlation between the construct and the variable (loading factor) has met Convergent Validity. The t-count value obtained for each loading factor for the 4 dimensions of the latent variable Leadership Style (X1) is more than 1.96 so it can be said that the manifest variable which is used meaningfully in measuring the variable Leadership Style (X1). The loading factor value is above the recommended value of 0.60 so that none of the constructs (manifest variable) for Leadership Style (X1) are eliminated from the model.

Based on the calculation of factors and t-statistics, it is known that there are 4 dimensions of Leadership Style which have a positive and significant relationship in determining the Leadership Style.

Table 3. Measurement Model Motivation Variable

\begin{tabular}{|c|c|c|c|c|c|c|}
\hline $\begin{array}{c}\text { Diment } \\
\text { ion }\end{array}$ & $\begin{array}{c}\text { Load } \\
\text { Facto } \\
\mathrm{r}(\lambda)\end{array}$ & $\lambda^{2}$ & $\mathrm{e}$ & $\begin{array}{c}\text { Measur } \\
\mathrm{e} \\
\text { Model }\end{array}$ & $\begin{array}{c}\mathrm{t} \\
\text { hitung }\end{array}$ & $\begin{array}{c}\mathrm{P} \\
\text { value }\end{array}$ \\
\hline $\begin{array}{c}\text { Motiva } \\
\text { tion }\end{array}$ & 0.883 & 0.781 & 0.219 & $\begin{array}{c}\mathrm{X}_{21}= \\
0,883 \mathrm{X} \\
{ }^{+}+ \\
0,219\end{array}$ & $\begin{array}{c}28.43 \\
4\end{array}$ & 0,000 \\
\hline relation & 0.852 & 0.725 & 0.275 & $\begin{array}{c}\mathrm{X}_{21}= \\
0,852 \mathrm{X} \\
{ }^{+} \\
0,279\end{array}$ & $\begin{array}{c}18.30 \\
6\end{array}$ & 0,000 \\
\hline $\begin{array}{c}\text { authorit } \\
\mathrm{y}\end{array}$ & 0.841 & 0.707 & 0.293 & $\begin{array}{c}\mathrm{X}_{23}= \\
0,841 \mathrm{X} \\
2^{+} \\
0,293\end{array}$ & $\begin{array}{c}15.59 \\
3\end{array}$ & 0,000 \\
\hline
\end{tabular}

The results from calculating the Loding factor value for the 3 dimensions of the Latent Motivation variable (X2) with a value range from 0.8 to 0.9 . The calculation results of the outer model value or the correlation between the construct and the variable (loading factor) have met Convergent Validity. The loading factor value is above the recommended value of 0.60 so that none of the constructs (manifest variable) for Motivation are eliminated from the model. The t-count value obtained for each loading factor for the 3 dimensions of the latent variable Motivation (X2) is more than 1.96 so that it can be said that the dimensions used are significant in measuring the variable Motivation (X2). Based on the results of the calculation of the loading factor and t-statistic, it is known that there are 3 dimensions of motivation that have a positive and significant relationship in determining motivation.

\subsubsection{Work Structure Variable Measurement Model}

There are 4 dimensions as measurable variables (manifest variable) that make up the Job Structure variable. For each variable, the factor weights are obtained in forming the Job Structure variable as follows:

Table 4. Measurement Model of Performance variables

\begin{tabular}{|c|c|c|c|c|c|c|}
\hline \multirow{2}{*}{ Dimensi } & \multirow{2}{*}{$\begin{array}{c}\text { Load } \\
\text { Facto } \\
\mathrm{r}(\lambda)\end{array}$} & \multirow[b]{2}{*}{$\lambda^{2}$} & \multicolumn{3}{|c|}{ Measur } & \multirow[b]{2}{*}{$\begin{array}{c}\mathrm{P} \\
\text { value }\end{array}$} \\
\hline & & & $\mathrm{e}$ & $\begin{array}{c}\mathrm{e} \\
\text { Model }\end{array}$ & $\mathrm{t}_{\text {hitung }}$ & \\
\hline $\begin{array}{l}\text { Worklo } \\
\text { ad }\end{array}$ & 0.697 & 0.486 & 0.514 & $\begin{array}{c}X_{3.1}= \\
0,679 X \\
3^{+} \\
0,514\end{array}$ & $\begin{array}{c}10.55 \\
8\end{array}$ & 0,000 \\
\hline $\begin{array}{c}\text { Job } \\
\text { Functio } \\
\text { n }\end{array}$ & 0.805 & 0.647 & 0.353 & $\begin{array}{c}X_{3.2}=0 \\
805 X_{3}+ \\
0,353\end{array}$ & 9.72 & 0,000 \\
\hline $\begin{array}{l}\text { Work } \\
\text { relation }\end{array}$ & 0.682 & 0.466 & 0.534 & $\begin{array}{c}X_{3.3}= \\
0,682 X \\
3^{+} \\
0,543\end{array}$ & 5.332 & 0,000 \\
\hline $\begin{array}{l}\text { Work } \\
\text { adjustm } \\
\text { ent }\end{array}$ & 0.704 & 0.496 & 0.504 & $\begin{array}{c}X_{3.4}= \\
0,704 X \\
3^{+} \\
0,504\end{array}$ & 8.061 & 0,000 \\
\hline
\end{tabular}

The results from calculating the Loding factor value for 4 manifest variables of the latent variable of Job Structure (X3) with values range from $0.6-0.9$. The results of the calculating the outer model value or the correlation between the construct and the variable (loading factor) have met Convergent Validity. The loading factor value is above the recommended value of 0.60 so that no construct (manifest variable) is eliminated from the model. The t-count value obtained for each loading factor for 4 manifest variables of the latent variable Job Structure (X3) is more than 1.96 so let's say that the dimensions used are meaningful in measuring the Job Structure variable (X3).

Based on the results of the calculating the loading factor and t-statistic, it is known that there are 4 dimensions of the work structure which have a positive 
and significant relationship in determining the work structure.

\subsubsection{Employee Performance Variable Measurement Model}

There are 4 dimensions as a measure (variable manifest) form the Employee Performance variable. For each dimension, the factor weights are obtained in forming the Employee Performance variable as follows:

\begin{tabular}{|c|c|c|c|c|c|c|}
\hline $\begin{array}{l}\text { Dimenti } \\
\text { on }\end{array}$ & $\begin{array}{c}\text { Load } \\
\text { Fact } \\
\text { or } \\
(\lambda)\end{array}$ & $\lambda^{2}$ & $\mathrm{e}$ & $\begin{array}{l}\text { Measu } \\
\text { re } \\
\text { Model }\end{array}$ & $t_{\text {hitung }}$ & $\mathrm{P}$ value \\
\hline \multirow{4}{*}{$\begin{array}{l}\text { Work } \\
\text { quality }\end{array}$} & & & & $Y_{1}=$ & & \multirow{4}{*}{0,000} \\
\hline & & & & $0,877 \mathrm{Y}$ & & \\
\hline & 0.87 & 0.77 & 0.23 & + & 42.7 & \\
\hline & 7 & 0 & 0 & 0,230 & 07 & \\
\hline \multirow{3}{*}{$\begin{array}{c}\text { work } \\
\text { quantity }\end{array}$} & & & & $\begin{array}{c}Y_{2}= \\
0.810 Y\end{array}$ & & \multirow[b]{2}{*}{0,000} \\
\hline & 0.81 & 0.65 & 0.34 & + & 13.7 & \\
\hline & 0 & 7 & 3 & 0,343 & 33 & \\
\hline \multirow{3}{*}{$\begin{array}{c}\text { punctua } \\
\text { lity }\end{array}$} & & & & $\mathrm{Y}_{3}=$ & & \multirow{3}{*}{0,000} \\
\hline & & & & $0,839 \mathrm{Y}$ & & \\
\hline & 0.83 & 0.70 & 0.29 & + & 16.5 & \\
\hline \multirow{4}{*}{$\begin{array}{c}\text { effectiv } \\
\text { eness }\end{array}$} & 9 & 3 & 7 & $\begin{array}{c}0,297 \\
Y_{4}=\end{array}$ & 25 & \multirow{4}{*}{0,000} \\
\hline & & & & $0,747 \mathrm{Y}$ & & \\
\hline & 0.74 & 0.55 & 0.44 & + & 11.0 & \\
\hline & 7 & 9 & 1 & 0,441 & 71 & \\
\hline
\end{tabular}

Table 5. Measurement Model Employee Performance Variable

The results of calculating the Loding factor value for 4 manifest variables of the latent variable Employee Performance $(\mathrm{Y})$ with range value from $0.7-0.9$ are already above the average for loading factor of 0.6. The results of the calculation of the outer model value or the correlation between the construct and the variable (loading factor) have met Convergent Validity. The loading factor value is above the recommended value of 0.60 so that no construct (manifest variable) for employee performance is eliminated from the model. The tcount value obtained for each loading factor for 4 manifest variables of the latent variable Employee Performance (Y) is more than 1.96 so it can be said that the manifest variable used is significant in measuring the Employee Performance variable (Y). Based on the results of the calculation of factors and t-statistics, it is known that there are 4 indicators of employee performance that have a positive and significant relationship in determining employee performance.

\section{CONCLUSION}

Leadership style, work motivation, organizational commitment and work performance appraisal together have a significant effect on job satisfaction of employees of Muara Enim Health Cente.

Leadership style has a significant influence on job satisfaction of employees of the Muara Enim Health Center, this indicates that a good leadership style will increase employee job satisfaction.

Work motivation has an effect but not significant to the job satisfaction of the employees of the Muara Enim Community Health Center, this proves that the lack of work motivation of the employees will have an impact on the low job satisfaction of employees.

Organizational commitment has a significant effect on job satisfaction of employees of the Muara Enim Community Health Center, this indicates that good organizational commitment will increase employee job satisfaction.

Performance appraisal has an effect but not significant on job satisfaction of employees of the Muara Enim Health Center, this proves that the lack of job performance appraisals will have an impact on the low level of employee job satisfaction.

It is recommended to the head of the Puskesmas in Muara Enim Regency to always improve leadership styles such as being an example and role model for employees in order to increase job satisfaction by motivating employees' work which is needed in an effort to increase employee job satisfaction so that ultimately performance increases. Organizations through their leadership must be committed and fair in assessing work performance so that employee performance can be measured so that employee job satisfaction increases. For further research, it is hoped that it can add to the variables studied such as providing incentives, supervision, training, work environment and division of labor and can increase the number of the population studied by a larger number.

\section{ACKNOWLEDGMENT}

This research was supported by State Polytechnic of Sriwijaya, Indonesia. The authors thank our colleagues who provided insight and expertise that greatly assisted the research.

\section{REFERENCES}

[1] Regulation of the Minister of Health of the Republic of Indonesia No. 75 of 2014, "Upaya Kesehatan Masyarakat". 
[2] Ministry of Health of the Republic of Indonesia, "Pemberian Obat Pencegahan Massal Filariasis", 2015.

[3] Ainurahmah, Yusni, "Pengaruh Manajemen Pusat Kesehatan Manyarakat terhadap Akses Pelayanan Kesehatan untuk mewujudkan Mutu Pelayanan Kesehatan", Jurnal Publik, P-ISSN: 1412-7063, E-ISSN: 2579-9266, 2015.

[4] The report on the implementation of the activity of giving mass prevention drugs for filariasis Pemerintah Kabupaten Muara Enim, 2016.

[5] Yulk, Gary, "Kepemimpinan Dalam Organisasi”, Jakarta: Indeks, 2012.

[6] Thoha, Miftah, "Kepemimpinan dalam Manajemen", Jakarta: PT Raja Grafindo Persada, 2015.
[7] Sutikno, Edy, "Manajeman Sumber Daya Manusia", Jakarta: Prenada Medika Group, 2016.

[8] Robbins Stephen \& Judge, Timothy, "Perilaku Organisasi”, Jakarta: Salemba Empat, 2017.

[9] Dessler, Gary, "Manajemen Sumber Daya Manusia”, Jakarta: Salemba Empat, 2016.

[10] Candra, Kusuma \& Tri Ratnasari, Ririn, "Evaluasi Kinerja Sumber Daya Manusia", Yogyakarta: Gosyen, 2017.

[11] As'ad, Muhammad, "Psikologi Industri", Yogyakarta: Liberty, 2002. 